\title{
Evli Kadında Soyadı Sorunu ve Kimlik Kaybı Üzerine Bir Değerlendirme
}

\author{
DOI: 10.26466/opus.762417
}

*

\author{
Ibrahim Aksakal * \\ * Öğretim Görevlisi, Erzincan Binali, Yıldırım Üniversitesi, Eğitim Fakültesi, Erzincan/Türkiye \\ E-Posta: ibrahimaksakal25@hotmail.com \\ ORCID: 0000-0002-3367-3194

\section{$\ddot{O} z$}

Evlenen kadının soyadı sorunu birçok araştırmaya konu olmuş, üzerinde çeşitli fikirler beyan edilmiştir. Bu çalışmada temel amacımız yapılan diğger araştırmalardan farklı olarak kadının yaşadığ "soyadı sorunu" ile "bireyde kimlik ve benlik inşası" konusunu bir araya getirerek olası bir kimlik kaybı yaşanıp yaşanmadığın değerlendirmektir. Araştırmamız, "evlenen ve belki daha sonra boşanan kadınlarda yaşanan soyadı değişiklikleri onlarda bir kimlik kaybı veya benlik algısı sorunu yaşatmakta mıdır?" problemi üzerinden yürütülmüs ve bu problemin cevabı aranmaya çalışılmıştır. Bu amaçla önce "kadında soyadı sorunu", "bireyde benlik ve kimlik inşası" ve "bireyin kendine yabancllaşması" alt başlıkları ele alınmış, ardından da araştırma problemimiz elde edilen bilgiler doğrultusunda değerlendirilerek sonuç elde edilmiş ve çeşitli önerilerle çalışma sonlandırılmıştır.

Bilindiği üzere kadın, yüzyıllar boyunca hayatındaki iki egemen erkekten birine, babaya veya kocaya bağımlı olmuştur. Bu bağımlılık durumu her ne kadar kadın lehine yaşanan gelişmelerle birlikte nispeten azalsa da tamamen ortadan kalkmış değildir. Çünkü bu eril tahakküm durumu özellikle bazı yaşam alanlarında günümüz toplumlarında hâkim gelenek olarak hâlâ devam etmektedir. Soyadı uygulaması da bu bağımlılı alanlarından sadece biridir. Çalışmamızda, "kadın, kendisine doğumla birlikte verilen ve zamanla kimliğinin bir parçası haline gelen soyadın ve dâhil olduğu aile kaydını evlenme ve boşanma aşamasında değiştirince olası bir kimlik ve benlik bunalımı söz konusu olacaktır" hipotezinden hareket edilmiştir. Kaynak taraması yapılmış, konu ile ilgili araştırmalar incelenmiş ve elde edebilen bilgiler, bu çerçevede değerlendirilerek yaşanan "kimlik kaybı" ve "benlik algısı problemi" ortaya konulup çeşitli çözüm önerilerinden bahsedilmiştir.

Anahtar Kelimeler: Toplumsal cinsiyet eşitsizliği, kadının soyadı, aidiyet sorunu, kimlik kaybı, benlik algist. 


\title{
A Explication Abaout The Problem Of The Married Woman's Surname And Loss Of Identity
}

\begin{abstract}
The surname problem of the married woman has been the subject of many studies and various ideas have been declared. Our main purpose in this study is to evaluate whether there is a possible loss of identity by bringing together the "surname problem" experienced by the woman and "identity and self-building in the individual" unlike other researches. Our research, "Does the changes in surnames in women who get married and maybe divorced later cause them an identity loss or self-perception problem?" problem has been carried out and the answer to this problem has been tried to be searched. For this purpose, firstly the subtitles "surname in women", "self-identity and identity-building in the individual" and "self-alienation of the individual" were discussed, and then our research problem was evaluated in accordance with the information obtained, and the results were concluded and the study was ended with various suggestions.

As it is known, women have been dependent on one of the two dominant men, father or husband for centuries. Although this addiction situation has decreased relatively with the developments in favor of women, it has not been completely eliminated. Because this masculine domination still continues as a dominant tradition in today's societies, especially in some living areas. Last name application is just one of these addictive areas. Our study is based on the hypothesis that "when the woman changes her surname and family record, which was given to her at birth and became a part of her identity in time, during the marriage and divorce phase, there will be a possible identity and self crisis". A literature review was conducted, researches related to the subject were examined and the information that could be obtained were evaluated in this framework, and the "loss of identity" and "self-perception problem" were presented and various solutions were mentioned.
\end{abstract}

Keywords: Gender inequality, woman's surname, belonging problem, loss of identity, perception of self 


\section{Giriş}

İnsanoğlu dünyaya ruhsal olarak "tertemiz", bir organizma olarak da tamamen doğal bir halde gelmektedir. Geride biraktığı her gün ve hatta her an doğallığından uzaklaşıp "insan olma" yolunda ilerlemektedir. Bu süreç sosyalleşme olarak da adlandırılabilir. Sosyalleşme süreci zamanla onu yapay bir varlığa dönüştürür. Sahip olduğu kişiliği, yetenekleri, değerleri, davranış biçimleri, kılık kıyafet tarzı, duyguları, beklentileri, inançları, kural ve kaideleri ve bunun gibi bir sürü, insanı havyandan ayıran şey bireye toplum tarafından sonradan tedricen kazandırılır. Yani dünyaya bomboş ve doğal bir vaziyette gelen insan yavrusu zamanla yapılandırılmış bir varlığa dönüşür.

İnsanoğlu canlılar dünyasında yardıma en uzun süre ve en kapsamlı biçimde ihtiyacı olan varlıktır. Çünkü diğer canlı türlerinden daha kompleks bir yaşama atılmaktadır ve yaşam biçimi onun çok yönlü olmasını gerektirmektedir. İnsanın maruz kaldığı sosyalizasyon süreci yaşam boyu devam etmektedir ve bu kaotik ortamda başarılı olmak için adeta kendini dış dünyaya teslim etme durumu ile karşı karşıya kalmaktadır. Yani doğduğu andan itibaren bir yetişkinin istekleri doğrultusunda yaşamaya başlayan birey bu durumu hayat boyu sürdürür ve nihayetinde toplumun onu çepeçevre sarmasına izin verir. Bu gün 'insanın mutluluğu, içinde bulunduğu ortama uyumu ile mümkündür' görüşü hâkimdir. Bu haklı ve aynı zamanda zaruri olan bakış açısı bireyin bütün hayatının toplum tarafından belirlenmesi ve buna bağlı olarak da adeta pasif bir varlığa dönüşmesini de beraberinde getirmektedir. Toplum, insanı biçimlendirme ihtiyaç duyar ve onu kendi ihtiyaçları ve kuralları çerçevesinde yetiştirir. Gelenekler, inançlar, değerler, kanunlar ve bunun gibi daha birçok toplumsal unsur bireyin yetiştirilmesinde etkili olur.

Çocuk, doğar doğmaz onunla ilgili ilk merak edilen şeylerden biri cinsiyetidir ve yeni doğan bebeğin cinsiyetini anlamının tek yolu cinsel organına bakmaktır. Kız ile oğlan cinsiyeti arasında bize görünen tek fark budur (Bhasin, 2003, s: 8). Yani Tanrı insanı kadın ve erkek olarak ayırmış, fakat bedensel anlamda onları çok küçük bir farkla yaratmıştır. Bu nedenle yeni doğmuş olan bir bebeğe uzaktan bakıldığında onun kız ya da oğlan olduğunu anlamak mümkün değildir. Yani kadın ve erkek yaratılış itibariyle fiziksel anlamda birbirlerine oldukça benzerlerken toplum tarafından mü- 
dahale edildikten sonra birbirlerinden oldukça farklılaşmaktadırlar. Öyleyse şunu söylemek mümkündür; bugünün kadın ve erkeği Tanrısal değil sosyal ve yapay bir görüntüye sahiptir. Zira Tanrı, isteseydi kadını uzun saçlı erkeği ise kısa saçlı yaratabilirdi. Fakat toplumlar sosyalizyon sürecinde kadın ile erkeği hem bedensel imaj anlamında hem de sosyal rol ve statü bakımından oldukça farklılaştırmıştır. Bu gelenek on binlerce yıldır toplumlar tarafından yaşatılmakta ve desteklenmektedir. Bu konu literatürde toplumsal cinsiyet (Gender) olarak ele alınmaktadır. Freud'un ifadesiyle bu tartışma konusunun merkezinde daha çok kadın olsa da münhasıran erkekleri daha fazla ilgilendirmiş, kadınlar bu bulmacanın içinde pasif nesneler olarak varlığını sürdürmüştür. Bir insana rastladığınızda, hemen kadın mi, erkek mi olduğunu görürsünüz; hatta onda göze çarpan ilk şey budur. Bu ayırt etmeyi son derece güvenle yapmaya alışmışsınızdır, der Freud (Freud, 1994). Freud'un bahsettiği bu ayırt etme alışkanlığı günümüz toplumlarının dikotomik ilişkiler saplantısıyla yakından ilgilidir ve en yaygın biçimde kullandığımız ${ }^{1}$ bu ilişki biçimi bir toplumsal cinsiyet (gender) meselesidir. Bhasin'in de ifade ettiği gibi bu toplumsal cinsiyet meselesi, sosyokültürel ve insan icadı bir konudur (Bhasin, 2003, s. 9).

Ebeveynler doğan çocuğa cinsiyetine göre bir ad verirler ve yine cinsiyetine uygun renklerle tasarlanmış kıyafetler giydirirler. Bunun neden yapıldığ 1 pek bilinmese de bütün toplumlarda ve bütün kültürlerde kadim bir uygulamadır ve günümüz toplumlarında halen kabul görüp sürdürülmektedir. Pilcher bugün İngiltere ve ABD'de de yeni doğmuş bebeklere cinsiyetine özgü isimler verildiğini, çift cinsiyetli veya cinsiyetten bağımsız isimlerin pek nadiren kullanıldığını ve bu durumun çok güçlü bir külttürel uygulama olduğunu ifade etmektedir. Lieberson ve ark. (2000)'de kadınlar için kullanılan isimlerin \% 97'sinin "feminen" isimlerden ve yine erkekler için kullanılan isimlerin \% 97'sinin ise maskülen isimlerden seçildiğini söylemektedir (Pilcher, 2017, s: 814). Bu araştırma sonuçları göstermektedir ki sadece geleneksel toplumlarda değil batılı toplamlarda da cinsiyetçi isim uygulamaları devam etmektedir. Böylece ebeveynler çocuklarının aldıkları isimlerle cinsiyet kimliği edinmesinde ilk adımı atmalarına zemin hazırla-

\footnotetext{
${ }^{1}$ Çeşitli sosyal psikologlar insanları fiziksel özellikleri bakımından çeşitli kategorilere ayırdığımızı ve bunu yaparken kadın ya da erkek kategorisine yerleștirme eğiliminde olduğumuzu ifade eder (Aranson, Wilson, ve Akert, 2012)
} 
maktadır. Çocuk aldığı bu isimle cinsiyetiyle ilgili önemli bir ipucu vermeye başlar ve kendi cinsiyet kategorisine uygun hale gelir. Toplumda yaygın bir şekilde insanları kategorilendirme ve çeşitli sınıflara ayırma ihtiyacı ya da geleneği vardır. Bu bizim sosyal hayatımızı oldukça kolaylaştırır ve çeşitli standartlar oluşturur. Hogg ve Abrams kategorilendirme biçimlerinden en yaygın olanlarından birinin cinsiyet sinıflandırması olduğunu ve bu sınıflandırma biçiminin hem toplumsal yapıyı hem de beraberinde kişiler arası ilişkiyi etkilediğini ifade etmektedir (Hogg ve Abrams, 1998, s. 13). Bizler bir insanla iletişime girdiğimizde en çok dikkat ettiğimiz özelliklerinden biri şüphesiz ki onun cinsiyetidir. Çünkü toplumsal norm ve değerlerde cinsiyet değişkeni önemli bir yere sahiptir. Ayrıca bir erkeğe hanımefendi diye hitap etmek de, bir kadına beyefendi diye hitap etmek de onu oldukça rahatsız edecektir. İnsanlar gerek isimleriyle, gerekse dış görünüşleriyle cinsiyetini belli etme ihtiyac duyarlar ve etraflarından da cinsiyetine uygun muamele görmek isterler. Bu nedenle çocuklar doğduklarında cinsiyetlerini belli eden bir isim verilir ve yine cinsiyetlerini belli eden kıyafetler giydirilir. Artık bebek değil erkek bebek ya da kız bebektir ve etraftaki insanlar cinsiyetiyle beraber onunla ilgili pek çok şey öğrenmiş olacaktır. Çocuğa ebeveynleri tarafından verilen ve kendisinin tercih etme konusunda hiçbir şansı olmadığı adı ve soyadıyla birlikte sosyalizasyon sürecinde önüne cinsiyetçi kıyafetler, meslekler, boş zaman faaliyetleri, dış görünüş, davranış biçimleri ve daha birçok şey konulmaktadır. Daha önce de ifade ettiğimiz gibi kendini dış dünyanın kontrolüne teslim etmiş olan birey genelde bu cinsiyetçi ayrımların farkına bile varmadan, önüne konulan gelenek unsurların önce hayatına daha sonra da kişiliğine katmakta ve dinamik yapıda olan benlik ve kimliğinin bir parçası haline getirmektedir.

Sosyolog Norbert Elias ad ve soyadlarm bireyin kimlik ve benlik algisına etki ettiğini iddia eder. Ona göre ad, bireyin "kişisel" kimliğini göstermede, soyadı ise "biz" kimliğini işaret etmede etkilidir (Pilcher, 2017, s: 816). Soyadı bireyin ait olduğu grubu gösterirken onu tekil olmaktan alıp sosyal bir grubun parçası haline getirmektedir. Bu durum da zamanla onun duygu, düşünce ve davranışlarına etki ederek kolektif bir kimlik ve benlik oluşturmasını sağlar. Bu hususta sosyal psikologların ortaya attı̆ı ve bizim de konumuzu yakından ilgilendiren bir başka konu da benlik sınıflandırmalarıdır. Myer (2015) ve beraberinde birçok sosyal psikolog, kişisel ve sosyal olmak üzere iki tür kimlik ve benlikten bahsetmektedir. Myer, bireyin ken- 
dinden bahsederken kendine ait özelliklerini kullanyorsa (ben uzunum, güzelim, zekiyim gibi) kişisel kimliğinin ön planda olduğunu ve kendinden müstakil bir karaktere sahip olduğunu, içinde bulunduğu grubun kendisiyle paylaştığı, yani gruba ait özelliklerden bahsediyorsa (ben Almanım, ben Müslümanım gibi) sosyal kimliğinin ön planda olduğunu ve karşılıklı bağımlı kimliğin daha baskın olduğunu ifade etmektedir. Yani birey birinci yolu seçiyorsa bireyci kimlik tipinin, ikinci yolu seçiyorsa toplulukçu kimlik tipinin baskın olduğunu iddia etmektedir (Myers, 2015, s: 35). Asya, Afrika ve Amerika'nın Merkez ve Güney kısımlarının çoğu -ki Türkiye bu gruba dâhildir- toplulukçu kimliğe sahip bireylerden oluşan toplumlardır. Bu tip bireyleri, Shinobu Kitayama ve Hazel Markus'un adlandırmasıyla karşıllklı bağımlı kimlikler olarak da ifade edebiliriz. Bu tip insanlar için dâhil oldukları grup ve bu grubun normları kendi kişisel tercihlerinden daha önceliklidir (Myers, 2015, s. 42). Bu tip bireyler kendilerini içinde bulundukları gruplara, diğer kimlik tipindeki bireylere göre daha çok ait hissederler. Eğer aile veya arkadaş gruplarından ayrılırlarsa kendilerini tanımlamak için kullandıkları sosyal bağlarından kopmuş olurlar. Bu da sonraki aşamada benliklerinin değişmesi ya da benlik kayması gibi durumlar doğuracaktır (Myers, 2015). Greenwald (1980), insanların kim olduklarıyla ilgili algilarını sürekli yeniden inşa ettiklerini ve bu yaptıklarının farkında olmadıklarını ifade etmektedir (Hogg ve Vaughan, 2014, s. 130). Sosyal bir varlık olan insanin algisını oluşmasında ve beraberinde kendisini yeniden inşa etmesinde sosyal konumu ve karşılıklı ilişkileri başat faktördür. Bilgin, kimliğin kültürel, tarihsel ve sosyal bir inşa olduğu konusunda sosyal bilimcilerin aynı fikirde olduğunu ifade etmektedir (Bilgin, 2007, s. 59).

Daha önce de ifade ettiğimiz gibi birçok sosyal psikolog kolektif kimlik tipinden bahsetmekte ve bölgesel farklılıklar olsa da Türk toplum yapısında kolektif kimlik türünün daha yaygın olduğunu ifade etmektedir. Erkek egemen bir yapıya sahip olan Türk toplumunda evli kadınlar genellikle kocasının soyadını alarak daha önce kazanmış olduğu sosyal kimliğini değiştirmekte, akabinde aidiyet hissini güncellemekte ve artık kendini bu yeni durumla yeniden inşa etmektedir. Öyleyse kadın, gerek kocasının soyadını alarak gerekse yine onun akrabalık sistemine dâhil olarak bir kolektif kimlik değişimine maruz kalmaktadır. Şayet kadın kocasından boşanır ise soyadını ve evlendikten sonra dahil olduğu akrabalık sistemini de kaybedecek ve bu 
durum ikinci bir kimlik karmaşası, aidiyet problemi ve kimlik inşası sorunu doğuracaktır.

Bu çalışmada amacımız evlenen kadının yaşadığı soyadı ve aile kaydı değiş̧ikliğinin ortaya çıkartacă̆ı olası kimlik kaybı durumunu ele alarak değerlendirmektir. Bu bağlamda kadının soyadı sorunu, bireyin benlik ve kimlik inşası ve kişinin kendine yabancılaşma konuları ayrı ayrı ele alınmış, ardından birbiriyle ilgili bu konular ortak bir zeminde tartışlarak değerlendirilmiştir.

\section{Kadının Soyadı Sorunu}

Adlar, insanların toplum içinde birbirlerini tanıması ve diğerlerinden ayırması için kullanılmıştır ve yine aynı amaçla zaman zaman ikinci bir ada ihtiyaç duyulmuştur. Bu ikinci ad genellikle kişinin (Uzun Hasan, Güzel Ayşe gibi) kişisel özelliklerinden seçilmiştir (Moroğlu, 2012, s: 1). Bu uygulamalar toplumlar çok kalabalık değilken işe yaramış ve yeterli olmuştur, fakat nüfusun iyice kalabalıklaşması ve kentleşme süreçlerinin ilerlemesiyle birlikte yetersiz hale gelmeye başlamıştır. Bu nedenle kentleşme süreci ilerde olanlar başta olmak üzere bütün toplumlar tedricen soyadı uygulamasına geçmiştir.

Soyadı uygulamasının tarihsel sürecine bakıldığında bütün toplumlarda uzun yıllar boyunca erkekler için bir kimlik belirleme unsuru olarak kullanıldığı ve kadının soyadının genellikle erkeğe bağlı olduğu görülmektedir (Moroğlu, 2012, s. 1). Evlilikle, karı koca hukukta bir kişi olarak değerlendirilmiştir, yani kadının yasal varlığı evlilik sırasında askıya alınmış veya en azından kocanınkine dâhil edilmiştir (W. Blackstone, 1941; akt. Lamber, 1973 ). Bu konunun temel sebepleri üzerinde araştırma konumuzun dişına çıktı̆̆ için ayrıntılı bir şekilde durmayacak olsak da birkaç cümleyle şöyle açıklayabiliriz. Abik'in de ifade ettiği gibi soyadı uygulaması kamusal alandaki karışıklığı önlemek amacıyla ortaya çıkmıştır. Soyadı, bir ev satın alırken, askere giderken, bankaya para yatırırken, okula kaydolurken belgelerde karışıklı̆ga engel olmak için önemli bir işleve sahiptir (Abik, 2005, s. 493). Fakat bu kamusal alan işlemlerinin hiçbirinde kadının yeri olmamıştır ve kadın adeta yüzyıllar boyunca kamusal alanda yok sayılmıştır. Her ne zaman ki toplum içinde kadının kamusal alanda varlığı söz konusu olmuş, kadın çalışmaya, eğitim almaya, sanatla uğraşmaya, seçmeye ve seçilmeye, ticaretle uğraşmaya başlamışsa işte o zaman onun da kimlik tespitinin ge- 
rekli olduğu düşünülmeye başlanmış ve erkeğin yanında bir birey olarak muamele görmesinin bir ihtiyaç ve bir kişisel hak olduğu tartışmaya açılmıştır. Bu gelişmeler Türk toplumunda on dokuzuncu yüzyıldan itibaren yaşanmış ve uzun mücadeleler sonrasında neticelenmiştir. Batılı toplumlarda da durum pek farklı olmamıştır. Batıda ilke olarak bir kadın kocasının uyruğunu almıştır. Kadınlar, Fransa ve İngiltere gibi bugünün modern toplumlarında bile evlilik öncesi kullandıkları soyadlarını bırakıp kocalarının soyadını almayı tercih etmiştir (Arnaud-Duc, 2005, s. 97).

$\mathrm{Bu}$ aşamada toplumların soyadı uygulamalarıyla ilgili birkaç bilgi paylaşmakta fayda olacaktır. Soyadı uygulaması devletlerin medeni kanunlarında düzenlenmekte ve bu uygulamanın yasal bir dayanağı bulunmaktadır. İnsanlar soyadı konusunda keyfi davranamamakta ve kanunların belirlediği sınırlar çerçevesinde soyadı sistemleri uygulanmaktadır. İnsanlar soyadını birkaç şekilde alabilmektedir. Bunlardan birincisi soyadı kanununun çıktığı dönemde gerçekleşmiş ve bu dönemde ailenin reisi olan erkeğe bir soyadı seçme hakkı verilmiştir. İnsanlar soyadlarını seçerlerken belli kurallar çerçevesinde tercih yapmıştır ve yine belli eğilimler göstermişlerdir. Bu tercihi yaparken kadınlar yok sayılmıştır, çünkü dönemin sosyal yapısı itibariyle kadın erkeğe bağımlı, onun himayesinde yaşayan ve resmi işlerde söz hakkı olmayan bir aile ferdinden ibarettir. Bu nedenle tercih edilen soyadlara bakıldığında feminen bir tercihle karşılaşmak pek mümkün değildir. Erkeklerin tercih ettiği soyadların doğal olarak daha çok cinsiyetleriyle, ait oldukları grup ya da milletle, meslekleriyle, yaşadıkları bölgelerle, sahip oldukları çeşitli özelliklerle ilgili olduğu görülmektedir. Dolayısıyla toplumda feminen soyadların pek tercih edilmemesi bu durumun tabiî bir sonucu olarak değerlendirebilir. Zira bugün Eroğlu, Saraçoğlu, Boduroğlu, Memetoğlu, Emiroğlu, Hancioğlu, Karaoğlu, Topaloğlu, Beyoğlu, Avcıoğlu, Köroğlu, Çobanoğlu, Türkoğlu, Bayramoğlu, Hatipoğlu, Müftüoğlu, İmamoğlu, Kasapoğlu, Aslanoğlu ve daha birçok örnek verebileceğimiz maskülen soyadlarıyla karşılaşılabiliyorken bunun tam tersini görmek pek mümkün değildir. Yani soyadlarının daha başlangıçta eril bir yapıya sahip olması kadınlar açısından en basit ifadeyle şansızlık ve gelecekte oluşacak çeşitli menfi temayüller için de bir sebep teşkil etmiştir. Özetle soyadı kanununun uygulama şekli etrafta bir sürü maskülen soyadlı kadının ortaya çıkmasına sebep olmuştur. 
İnsanlar soyadını ikinci bir yöntem olarak doğumla kazanmaktadırlar. $\mathrm{Bu}$ durum medeni kanunlarla düzenlenmiş ve her insana doğumla birlikte bir ad ve soyad alma hakkı verilmiştir. Medeni kanun, adı ve soyadı, kişi olma göstergesi ve kişilik elde etme aracı olarak kabul etmiş, dokunulmaz ve devredilmez bir hak, bireyselliğin ve kimliğin bir ifadesi olarak değerlendirmiştir (İlgöz, 2009). Ayrıca doğumla birlikte kazanılan ad ve soyadın değiştirilmesi kanunlar tarafından engellenmiş, bu değişiklik sadece haklı gerekçelere bağlanmıştır. Fakat bu konuda cinsiyetçi bir ayrım ortaya çkmış, evlenmekle birlikte kadının -çeşitli gerekçelerle- kocasının soyadını almak suretiyle soyad değişikliği yapması gerekli görülmüş, bu durum medeni kanunda erkek tarafgirliği ile düzenlenmiştir. Yeni düzenlemeler yapılana kadar -uzun yıllar boyunca - kadınlar evlendikleri zaman 'bir başka erkek olan babalarından aldıkları' soyadlarını değiştirip kocalarının soyadlarını almak durumunda kalmıştır (Aksakal, 2019). Şayet kadın birden fazla evlilik yaşamışsa söz konusu değişiklik evlilik sayısıyla paralellik gösterecek, kadının kimliği adeta bir oraya bir buraya savrulup duracaktır. Evlenen kadının sadece soyadı değil aynı zamanda aile kayıtları da değiştirilmiştir. Kadın, evlenince kocasının aile kütüğüne kaydedilmiş ve böylece erkeğin akrabalık sistemine dâhil edilmiştir. Bu evlilikten doğan çocuklar da babanın soyadını almakta ve yine babanın nüfus kütügüne kaydedilip akrabalık sistemine dâhil edilmektedir. Bu iki resmi prosedür kadının, evlenmekle birlikte ait olduğu kolektif yapıyı değiştirmesi ve bu bağlamda bir yeniden inşa süreci yaşaması anlamına gelmektedir. Bu konudaki düzenlemeler Nüfus Hizmetleri Kanunu ile yapılmıştır. NHK Madde 23-2; Evlenen kadının kaydı kocasının hanesine taşını. Kocası ölen kadın yeniden evlenmedikçe ölen kocasınm aile kütüğünde kalır. Ancak dilerse babasınn kütüğüne dönebilir (Nüfus Hizmetleri Kanunu, 2006). Bu kanun maddesi açıç̧a kadını evlenmekle birlikte kocasının himayesine sokmuş ve onun, kimlik kaybı yaşayarak erkek tahakkümüne maruz kalmasına zemin hazırlamıştır. Sadece bu kanun maddesi bile kadının toplum ve hatta kendisi tarafından pasif, sığıntı, zayıf, bağımlı, silik, eksik, ikinci cins gibi olumsuz sıfatlarla algılanmasına sebep olabilmektedir. Yine bu ve bunun gibi çeşitli yasal uygulamalar erkeği kadın tahakkümü karşısında haklı hale getirebilir veya öyle bir algıya sahip olmasina sebep olabilir. Bu ya da bu gibi kanun maddeleri acaba yine erkeğin kadına bir nesne olarak yaklaşıp o paralelde muamele yapmasına, belki de zaman zaman çeşitli talimatlar verilmesi gereken ve hatta bazen 
cezalandırılması gereken bir nesne gözüyle bakmasına sebep olabilir mi? Bu değerlendirmem elbette endazeyi kaçrmak olarak yorumlanabilir. Fakat olaya biraz psikoloji katılarak değerlendirildiğinde haklılık payımızın olduğu görülecektir. Ünlü psikolog Sigmund Freud, insanın aslında zannedildiği kadar kontrol sahibi bir varlık olmadığını, aksine bilinçaltından yönlendirilen pasif bir varlık olduğunu iddia etmektedir. Ona göre insanlar günlük yaşantıları sırasında çeşitli anılar biriktirirler ve bu anılar bilinçaltlarını, daha sonra da etrafı algılama biçimlerini etkiler. İşte bu algılar da bizlerin düşünce ve davranışları üzerinde etkiye sahiptir (Freud, 2011, s. 75-77). Karı koca ilişkisinde şayet çevredekiler ve özellikle otorite statüsünde olan kişi ya da kurumlar (devlet ve kanunlar, insanlar gözünde, onları derinden etkileyebilecek otorite konumundadır) kadına pasif, erkeğe egemen muamelesi yaparsa bir tarafın kendini olduğundan daha güçlü, diğer tarafın da tam tersine olduğundan daha zayıf görmesi hakikaten çok zor bir ihtimal olmayacaktır.

Hukuk sistemlerinde erkekler soyadlarını doğumla birlikte alıp tüm hayatları boyunca değiştirmeden kullanma ayrıcalığına sahipken, kadınlar sadece evlenirken değil aynı zamanda bir de boşanma durumu söz konusu olursa soyadı değişikliği karmaşası ile karşı karşıya kalmaktadır. Boşanma işleminden sonra erkek, soyadını değiştirmemektedir. Böylece hem kadında olduğu gibi yeniden bir kimlik edinme süreci ile karşı karşıya kalmamakta, hem de etraftakilere onun boşanmış bir yetişkin olduğuna dair bir ipucu verilmemektedir. Fakat boşanan taraflardan biri olan kadın için süreç daha farklı işlemektedir. Boşanma sonrasında şayet koca, eski karısının kendi soyadını kullanmasını istemiyorsa çeşitli gerekçelerle bunu engelleme hakkına sahiptir. Deyim yerindeyse, soyadını karısına ödünç veren koca daha sonra onu geri alma hakkı vardır (Arnaud-Duc, 2005, s. 97). Kadın, kocasından ayrıldıktan sonra soyadını yeniden değiştiriyor, yine bir başka erkek hegemonyasına geri dönüp babasının soyadını alıp bir süre önce bıraktığ kimliğine tekrar bürünerek yine ve yeniden kimlik inşası süreci ile karşı karşıya kalıyor. Belli bir dönem, kendini kocasının soyadıyla tanıyan ve topluma tanıtan kadın, boşandıktan sonra etrafa kimliğini yeniden sunmakta ve yeni bir sosyal kimlik oluşturma sorunuyla karşı karşıya kalmaktadır (İlgöz, 2009, s. 105). Ayrıca soyadını değiştiren kadın etraftakilere -kocanın aksine- boşanmış bir kadın olduğuna dair bir ipucu vermiş olmaktadır. Bu küçük ayrıntı özellikle geleneksel toplumlarda kişiler açısından önemli bir 
sorun olabilmektedir. Örneğin siyasette aile ilişkilerinin iyi işlemesi politika$\mathrm{cl}$ itibarı açısından önemlidir. Bu nedenle sık sık politikacıların eşleriyle boy boy pozlar verdiğini görmekte, sağlıklı bir evlilik sürdüklerine dair mesajlar almaktayız. Milli Eğitimin ilk kadın bakanı olan Nimet Çubukçu, eşinden ayrılmış, kocasından devraldığı soyadını boşanma işleminden sonra bırakmış ve eski soyadına geri dönmüştür. Siyasi kariyeri boyunca Nimet Çubukçu olarak tanınan politikacının eski soyadına dönmesiyle birlikte topluma bu sayede -Nimet Hanım'ın eşinden boşandığına dair- bir istihbarat sağlanmış, herkes onun eşinden boşanmış bir politikacı olduğunu her ne kadar basında pek gündeme gelmese de öğrenmiş ve belki de politikacı kimliği bundan zarar görmüştür. Fakat söz konusu politikacı erkek olsaydı belki de çok dikkat çekmeyecek ve onun politikacı kimliği bundan daha az etkilenecekti. Aynı sorun sadece tanınmış insanlar için değil belli bir sosyal çevreye sahip herkes için geçerlidir. Goffman'ın ifadesiyle boşanmış olmak toplumlarda zaman zaman damgalanma gerekçesi olabilmekte ve kişinin kariyerine, sosyal kimliğine ve ilişkilerine zarar verebilmektedir. Bu damga bireyin -her zaman ve her yerde geçerli olmasa da- sosyal hayatta diğerleriyle olan ilişkilerinde onu itibarsızlaştırabilecek bir özelliğe sahiptir (Goffman, 2018). Bu itibarsızlaştırma süreci kadını erkek karşısında daha zayıf kılmakta ve kimliğine zarar verebilmektedir. İnsanlar boşanmış birey olduklarını zaman zaman saklama ihtiyacı duyabilmektedir. Yani Goffman'ın ifadesiyle "damgalı" birey ihtiyaç duyduğunda ve mümkünse damgasını saklamak isteyecektir (Goffman, 2018). Bu durumda kadının soyadı değiştirme eylemi onu ele verecek ve boşanmış olduğunu saklaması mümkün olmayacaktır. Yani toplumdaki soyadı uygulaması, kadının damgasını saklamasına imkân tanımazken erkeğe saklama imkânı vermektedir.

Yukarıda da ifade ettiğimiz gibi ad ve soyadın değişmezliği hukuk sistemlerinde önemli bir ilkedir. Bu nedenden dolayı çağdaş hukuk sistemleri soyadı değiştirmenin önüne engeller koymuş, ad ve soyadı değişikliklerini haklı gerekçelerle mahkeme kararlarına bağlamıştır (Abik, 2005, s. 62). Soyadı değişikliği Türk Medeni Kanunu 27. madde ile şöyle düzenlenmiştir: TMK md. 27: "Adın değiştirilmesi, ancak haklı sebeplere dayanllarak hâkimden istenebilir" (Türk Medeni Kanunu, 2001). Bu maddenin uygulanma sürecinde soyadı değişikliği sadece erkek tarafından talep edilmekte ve kadının bu aşamada kimlik ve benlik değişimi kocasının inisiyatifine bırakılmaktadır (İlgöz, 2009, s. 109). 
Kadının, kocasının himayesine girmesi geleneği uzun yıllar devam etmiş ve hatta yasal düzenlemeler yapılmasına rağmen kadınlar bu uygulamadan kültürel yapı gereği vazgeçememiştir. Bu gün yapılan araştırmalar da bunu desteklemektedir ki Batılı toplumlar da dâhil olmak üzere kadınların büyük bir çoğunluğu evlendikten sonra kocalarının soyadını alıp kendi soyadlarından vazgeçmektedir. ABD'de yapılan bir araştırma ortaya koymuştur ki kadına kendi soyadını kullanabilmesini sağlayan yasal düzenleme yapılmış olmasına rağmen halâ, evlenen kadınların \% 94'ü eşlerinin soyadlarını kullanmaya devam etmektedir. Ve yine başka bir araştırmada evlenmemiş lisans öğrencilerinin çoğunluğu, evlendikten sonra soyadı konusunda geleneksel uygulamaya bağlı kalacaklarını ifade etmişlerdir. (Robnett, Underwood, Nelson, ve Anderson, 2016 , s. 501). Yapılan araştırmalardan elde edilen ve bugün kadınların soyadı sorunsalının devam etmesinde etkili olan, bir o kadar da ilginç çeşitli bilgiler şöyledir: Evlendikten sonra kocasının soyadın almayıp kendi soyadıyla devam eden kadınların eşlerine daha az bağlı olacaklarına, kadının kendi soyadını kullandığı evlilikte erkek otoritesinin zayıf olduğuna ve yine geleneksel yöntemi sürdürmeyen kadınların evliliklerine sıkıca bağlı olmayacaklarına dair çeşitli düşünce biçimlerinin yaygın olduğu ortaya çıkarılmıştır (Robnett, Underwood, Nelson, ve Anderson, 2016, s. 501).

Tarih boyunca, kadın hayatında iki egemen erkek olan baba ya da koca merkezli olan ad ve soyad uygulaması bizim bu çalışmada iddia ettiğimiz üzere kadının benlik ve kimliği üzerindeki bir erkek hegemonyası haline gelmiş ve kadının bağımsız bir birey olma hakkını elinden almıştır. Öyle ki kendini adı ve soyadıyla bir birey olarak algılayan kadının aslında taşıdığı soyadı ona hayatındaki egemen erkekler tarafından verilmiş bir emanetten başka bir şey değildir ve yine gerek duyulursa bu emanet geri alınarak yeniden bir inşa süreci yaşamakla karşı karşıya bırakılacaktır. Bu konunun ehemmiyetini gösterecek önemli bir örnek Alman hukuk sisteminden verilebilir. Her ne kadar hukuk sistemleri değiştirilmiş ve bir kısım uygulamaları terk edilmiş olsa da geleneklerin yerleşmesi ve hayatımıza etkisi bakımından yine de geçerli örnekler olacaktır. Alman hukukunda ad taşıma, kişi olmak için önemli bir temel gösterge kabul edilmiştir. Van Hokoben ve De Erney'in ifadesiyle alman hukuk sisteminde ismi olmayan çocuğu öldürmek suç olarak değerlendirilmemiştir (Abik, 2005, s. 48). Bu örnek sadece sosyal yaşamda değil aynı zamanda devletin resmi uygulama sistemlerinde 
de yani kanun ve devlet düzeyinde de ad ve soyadın kişi ve kişilik hakkı bakımından ne kadar önemli olduğunun bir göstergesidir (Aksakal, 2019). Adla ilgili bu örnek, ad almak ile gerçek bir birey olmak arasındaki bağlantıyı gözler önüne sermek bakımından önemlidir.

Özetlemek gerekirse ad ve soyadı benlik ve kimlik oluşturma sürecinde merkezi bir öneme sahiptir. Özellikle geleneksel toplumlar başta olmak üzere bütün sosyal sitemlerde insanlar soyadlarıyla ait oldukları akrabalık ve aile sistemlerini topluma bildirmiş ve etraftakiler tarafından bu şekilde tanınmışlardır. Kişi, soyadıyla sadece kendini etrafa tanıtmakla kalmıyor aynı zamanda benlik ve kimliğiyle ilgili kendine dair bir algı da oluşturuyor. Sahip olduğu soyadı bir birey olma, resmiyet kazanma, sosyal bir varlık hâline gelme gibi konularla birlikte bir karakter inşası da sağlamaktadır. Bu konuda Ouspensky (2010) şöyle der; İnsan iki kısımdan oluşmuştur. Öz ve kişilik. Insandaki öz, kendisine ait bulunandır. Kişilik ise 'kendisine ait olmayandır'. 'Kendisine ait olmayan'; dışarıdan gelmiş bulunanlar, öğrendikleri ya da kendisine aksedenler, bellekte ve duyumlarda kalan dış izlenimlere ait tüm izler, öğrenilmiş bütün kelime ve hareketler, taklit yolu ile doğmuş bütün duygular anlamına gelir. Bütün bunlar, 'ona ait değildir'; bütün bunlar kişiliktir." (Ouspensky, 2010, s. 129). Öyleyse biz burada Ouspenky'nin de ifadesinden yararlanarak şöyle söyleyebiliriz. Kadın, hayatındaki ilk egemen erkek olan babadan aldığ soyadıyla sahip olduğu sosyal kimlik ve karakterini, kocasından aldığı soyadıyla yeniden yapılandırıp inşa etmektedir. Bu işlem belki daha sonra yeniden evlenme ve boşanma durumlarında tekrar edebilecektir.

\section{Bireyde Benlik ve Kimlik Oluşumu}

Benlik ve kimlik, bireyin doğuştan değil, sosyalizasyon sürecindeki yaşantılarıla ve çevrenin önemli etkisiyle birlikte gelişen bir algılama ve tanımlama biçimidir. Daha önce de ifade ettiğimiz gibi bireyin kendini algılaması toplumun bireyi tanımlamasında bu kavram ön plana çıkmaktadır. Bu iki kavram sosyal varlık olan bireyin sosyal statüsünden kişisel tercihlerine kadar birçok konuda belirleyici olmakta ve onun adeta sosyal hayata açılan penceresi olarak işlev görmektedir. Sosyal kimlik ve benlik, bireyin kendisi ve etrafındakilerini algılamasını, davranış biçimlerini, neyi başarıp neyi başaramayacağını ve sosyal ilişkilerini etkilemektedir (Hogg \& Vaughan, 2014, s: 128) 
Kağıtçıbaşı (2010), bireyci ve toplulukçu olmak üzere iki tip benlikten bahsetmektedir. Ona göre bireyin hangi kimlik tipine sahip olacağı özellikle içinde yaşadığı toplum tipiyle ilgilidir. Kültür, ne kadar bireyci olursa toplumdaki özerk benlikler o kadar yaygin olacaktır, yine toplum ne kadar toplulukçu olursa o toplumda yaşayan ve ailesel bağları güçlü olup özgeci davranan bireyler de o kadar yaygin olacaktır (Kağıtçıbaşı, 2019, s: 127). Kağıtçıbaşı, özellikle doğu toplumları ve geleneksel toplumlarda toplulukçu ve bağımlı kimlik tiplerinin daha yaygın olduğunu ifade etmektedir. Bireyin özgür ya da bağımsız olması aldığı kararları, davranışları, sosyal ilişkilerini ve daha önemlisi aile içi ilişkilerini etkileyecektir. Hogg ve Vaughan da yine bireysel ve kolektif benlik türlerine açıklama getirmiş ve bireyin kendinden bahsederken kullandığı söylemlere dikkat çekmiştir. Şayet birisi kendinden bahsederken kişisel özelliklerini veya ismini söylüyorsa kişisel benliğinden bahsettiği, bunun tersine kendisi hakkında konuşurken ait olduğu gruptan bahsediyorsa kolektif benliğini yansıttığını ifade etmektedir (Hogg \& Vaughan, 2014, s: 129). Bu konularda çeşitli psikologların buluştuğu ortak nokta bireysel benlik ve kolektif benlik ayrımıdır. Fakat ister bireysel kimlik ve benlik olsun ister kolektif kimlik ve benlik olsun bir gerçek vardır ki o da bireyin benliğini oluştururken çevre koşullarının ve içinde bulunduğu grubun önemli bir etki gücüne sahip olduğudur. Mead, benliklerin oluşma sürecinde sosyal çevrenin büyük bir etkisi olduğunu ifade etmiş ve bireyin içinde bulunduğu ortamda çevresi tarafından nasıl yönlendirilir ve muamele görürse o şekilde benlik algısının oluşacağını söylemiştir (Hogg ve Vaughan, 2014). Yine Goffman şu ifadelerle benliğin oluşum sürecini açıklamaya ve çevre faktörünün etkisini vurgulamaya çalışmıştır. "Benlik oluşturma ve yaşatma araçlarn çoğu kez toplumsal kurumlarda bulunur. Vücudu biçimlendirmek için aletlerin olduğu bir arka bölge ve sabit dekoruyla bir vitrin bölgesi vardır. Kişilerden oluşan bir takım vardır ve bu takımın sahne üzerindeki faaliyetleriyle mevcut dekorlarm birleşiminden, canlandırlan karakterin benliği ortaya çıkar; ayrıca yorumlayıcı faaliyetleri bu oluşum için gerekli olan, seyirciler dediğimiz bir diğgr takım daha vardır. Benlik bütün bu düzenlemelerin bir ürünüdür ve her parçasında bu oluşum sürecinin izlerini taşır (Goffman, 2016, s. 235)".

Taylor ve arkadaşları kolektif kimliklerin bireyde çeşitli kalıp yargılar oluşturduğunu, bu kalıp yargılarla birlikte bireyin kendinde var ettiği benlik algısıyla kendini grubun bir parçası veya üyesi olarak görmeye başladığını ve bunun sonrasında ait olduğu grubun sosyal kimliğine uygun bir 
model haline geldiğini ifade etmektedir (Taylor, Peplau, ve Sönmez, 2012, s. 112). Bu konuda Turner ve Reynolds (2012), sosyal kimlik kuramı ve siniflandırma kuramlarından bahsetmiş ve insanların toplumsal olarak inşa ettiği kategoriler içinde nasıl davrandıkları ve düşündüklerine dair açıklamalar yapmışlardır. Sosyal kimlik kuramına göre birey olumlu benlik algisı geliştirme eğilimindedir ve bunu başarabilmek için çeşitli sosyal gruplara dâhil olur. Dâhil olduğu bu gruplar içinde kendilerine bir statü edinir ve kendi gruplarına karşı olumlu duygular geliştirir (Tajfel ve Turner, 1979, s.40; akt. Özkan, 2014). Kendini grubuyla özdeşleştiren birey bir taraftan grubuna karşı tarafgir davranırken diğer gruplara karşı pozisyon almakta, diğer taraftan da grubuna karşı özgeci davranışlar sergilemektedir. Grubun içerisindeki norm ve değerler grup üyesi bireyler tarafından benimsenir ve zamanla kişiliğin ve yaşam tarzının bir parçası hâline gelir. Aynı zamanda grubun diğer üyelerine karşı olumlu duygular geliştirilir ve zamanla grup üyeleri arasında benzer duygular, tutumlar ve alışkanlıklar ortaya çıkar (Gürlek ve Tuna, 2018). Turner'in ifadesiyle eğer grubun sosyal kimlik anlayışı baskın ise zamanla grup üyelerinde benlik yitimi (depersonalization) görülür ve bu durumda da grup üyeleri için grubun menfaatleri kişisel menfaatlerden öncelikli hale gelir (Özkan, 2014, s. 10). Bu durum bütün bireyler üzerinde aynı etkiye sahip olmayabilir. Bir toplum içindeki bütün bireyler bağımlı kimlik veya bağımsız kimlik tipine sahip olmazlar. Bireyin sahip olduğu benlik ve kimlik tipi kültürel etmenlerden, inanç sistemlerinden, yaşam biçimlerinden, eğitim seviyesinden, ekonomik unsurlardan, statüsünden, zaman zaman yaşından ve hepsinden önemlisi cinsiyetinden etkilenebilir. Aynı zamanda bir kişinin kimlik tipini tamamen bağımlı kimlik ya da tamamen bağımsız kimlik tipi olarak da sınıflandırmak doğru olmayacaktır. Şüphesiz ki her insanda her iki tipe ait özellikler de vardır fakat bunlardan biri daha baskındır. Turner'in bahsettiği kimlik yitimi aslında bütün insanları ilgilendirmektedir. Çünkü sosyal davranış, diğer insanları dikkate alarak yapılan davranıştır. Yani bir kişi herhangi bir davranışı sergilerken diğerlerinin varlığından etkilenerek davranışlarına çekidüzen veriyorsa buna sosyal davranış denir. Örneğin yalnızken esnemek sosyal bir davranış değildir, etrafta birileri varken esniyorsanız ve esnerken de ağzınızı kapamıyorsanız buna sosyal davranış denir. Dolayısıyla sosyal davranış, sınırlandırılmış davranış demektir ve yine sosyal insan demek davranışları sınırlandırılmış insan demektir. Sadece bazıları çevreden daha 
fazla etkilenirken bazıları ise daha az etkilenmektedir Özetle söylenebilir ki Turner'in bahsettiği kimlik yitimi toplum içerisinde yaşayan her bireyde gerçekleşmektedir fakat bağımlı kimlik ve kişilik özellikleri daha yoğun olan bireylerde bu durum diğer tip bireylere göre daha fazla yaşanmaktadır. Şimdi bu aşamada şu sorunun yanıtını aramak gerekmektedir. Burada tartıştı̆̆ımı kimlik yitimi durumunda cinsiyetin gerçekten kayda değer bir etkisi var mıdır? Geleneksel toplumlarda daha yoğun olmak üzere bütün toplumların genelinde sosyal kontrol mekanizması ve grupların normdeğer sistemleri kadın davranışları ve kimlikleri üzerinde daha yüksek bir yaptırım gücüne sahiptir. Kadınların içinde bulunduğu sosyal sistemin etkisi göz ardı edilemez, fakat yine de geleneksel yaşantı biçimleri toplumun geneline etki etmekte ve kadın kimlikleri üzerine daha fazla bir baskı uygulanmaktadır. Kendini topluma beğendirme, norm ve değerlere uygun davranma eğilimi bütün insanlarda olan bir özelliktir fakat toplumsal normlar gereği bu özellik kadında erkeğe göre daha fazla gözlenebilmektedir. Çünkü toplumlar kafalarında kusursuz bir kadın imajı geliştirmiş ve kadınların bu imaja uygun olmaları için çeşitli çabalar sarf etmişlerdir. Bu nedenle kadın, dâhil olduğu sosyal grupların kimliklerini edinirken dişil karakterin getirdiği dezavantajlarla birlikte sosyal kimliğini inşa etmekte ve erkeğe kıyasla daha fazla özgeci davranışlar sergilemektedir. Bu konuda Turner ve Reynolds'un bahsettiği bir başka kuram olan Kendini Sınıflandırma Kuramı'na göre birey bir gruba dâhil olduktan sonra o grubun norm ve değerleri aracılığıyla grubun diğer üyeleriyle arasındaki benzerlikleri artırmaktadır (Özkan, 2014). Yani birey bir gruba girdikten sonra o grup üyelerine olan benzerlikleri sürekli artarken bu grubun dışında kalan diğer grupların üyeleri ile de farklılaşmaktadır. Bu kural aslında sosyal grupların tabiatında vardır ve biz de Turner ve Reynolds' un bu iddiasını kabul etmekteyiz. Hal böyle olunca da kadının evlenmekle birlikte dâhil olduğu akrabalık sistemini değiştirmesi bir kat daha anlam kazanmış oluyor. Geleneksel toplumlarda yuvayı yapan dişi kuş statüsünde olan kadının aile için özgeci bir tavra sahip olması hatta kendini tamamiyle aileye adaması beklenmektedir. $\mathrm{Bu}$ adanma durumu şüphesiz ki kadının kimlik yitimi ve ardından yeniden kimlik inşa etme durumunu beraberinde getirecektir. Greenwald (1980), insanların bu durumunun insanın yaşam biçiminin doğasında olduğunu, kim olduklarını yeniden inşa etme eğiliminde olduklarını ve bunun da farkında olmadıklarını ifade etmektedir (Hogg \& Vaughan, Sosyal Psikoloji, 
2014, s.130). Bu iddia Freud'un insanın bilinçaltından yönlendirilen pasif bir varlı olduğu ve onun, zannedildiği gibi irade sahibi bir varlık olmadığı iddiasıla örtüşmektedir. Bu iki bilim adamının ortaya attı̆̆ı bu önemli iddia hak veriyor ve bu konuda son söz olarak şunu ifade ediyoruz. Kadınlar, kendilerinin bile çoğu zaman farkında olmadığı bir kimlik yitimi ve yeniden kimlik inşası oluşma süreci yaşamaktadır.

\section{Bireyin Kendine Yabancılaşması Üzerine}

Yabancılaşma, psikolojik, felsefi ya da sosyolojik açıdan tanımlanabilen bir kavramdır (Marshall, 1999). Bu aşamada bu kavramın çeşitli tanımları arasından bizi ilgilendirenini ele alıp konumuzu bu bağlamda tartışmaya çallşacağız. Cevizci (2005), yabancılaşmayı farklı bilim dalları açısından ele alarak şu şekilde tanımlamıştır; 1 . psikoloji için normalden sapma, 2. sosyoloji açısından kişinin kendisine, içinde yaşadığı topluma, tabiata ve başka insanlara karşı duyduğu yabancllık hissi, 3. felsefe açısından ise, şeylerin, nesnelerin bilinç için yabancı, uzak ve ilgisiz görünmesi, daha önceden ilgi duyulan şeylere, dostluk ilişkisi içinde bulunulan insanlara karşı kayıtsız kalma, ilgi duymama, hatta bıkkınlık ya da tiksinti duyma (Cevizci, 2005, s. 1728). Cevizci yabancilaşma kavramına açıklama yaparken, insanın içgüdü, tutku ve alışkanlıklarına işaret eder ve bunlardan dolayı kişinin kendisine ve özüne uzaklaştığını söyler. Bireyin bu durumda kendine özgü özelliklerinden, insani ilişki ve eylemlerinden uzaklaştığını, adeta cansız ve pasif bir nesneye dönüştüğünü söyler (Cevizci, 2005, s. 1728). Bu durumda birey kendi benliğinden uzaklaşarak artık kendine tabiattaki bir nesne gözüyle bakmaya başlar. Kendisine bilişsel ve duyuşsal anlamda mesafe bırakır ve birey kendisiyle olan teması yitirip kendinden kopar (Cevizci, 2005, s. 1728). Cevizci, bunlara ilaveten bireyin yabanclaşmasının toplumun norm ve değerlerinden uzaklaştığı ve toplumsal ilişkilerde dışlanmışlık hissine kapıldığı zaman ortaya çıtığını belirtmektedir. Kendine yabancılaşan birey doğal olarak gücünü kaybetmekte, yönünü belirlemekten aciz bir hale gelmekte, davranışları ve yaşantısı içsel dünyasıyla ilişkiyi koparmakta, kendi isteklerinden ziyade başkalarının istekleri üzerinden hayatını şekillendirmekte, toplumsal kurumlarının baskısı altında ezilip adeta kendini tüketmekte ve sonuç olarak tamamen dışarıdan yönlendirilen bir birey haline dönüşmektedir. Zaman zaman ben kimim ve nasıl biriyim diye kendini sorgulayacak olursa bunun cevabını yine 
ancak dışsal göstergeler yardımıyla verebilen bireyin içinde bulunduğu durumun başlıca sorumluları arasında toplumsal kurumlar vardır. Zira insan hayatında merkezi öneme sahip olan ve sosyal yaşamı çekip çeviren kurumların doğru ile yanlışı, yasal olan ile yasadışı olanı, günah ile sevabı, iyi ile kötüyü ve insan hayatının düzenlenmesi bakımından yaptırım gücü olan daha birçok değeri, normu ve kuralı belirleme yetkileri vardır. Bu yetki sayesinde toplumsal kurumlar bireyin kendileri ile ilgili herhangi bir konuda karar verirken kendilerine dönmelerine firsat vermeden verilen talimatlar ve gösterilen hedefler doğrultusunda davranmalarını sağlayabilmekte ve böylece öz kontrollerini kaybetmelerine sebep olmaktadırlar. Husserl'in şu tespitleri de tartışma konumuz açısından aydınlatıcı olacaktır. İnsanı çepeçevre saran kültür, onun gerek dünya içindeki yerini belirlemekte gerekse bütün aktivitelerinde bir konuma sahip bir sistem olarak çalışmaktadır. Bu sistem, insanın kendini anlamasına ve kendi olarak yaşamasına hizmet etmekten ziyade onun dünyaya ve kendisine yabancilaşmasına yol açmaktadır (Küçükkalp, 2010, s.38). Husserl'in iddiası bu konudaki tezimizle örtüşmektedir. Biz de burada çeşitli kurumların tahakkümünden kaynaklı bireyin yaşadığı yabancılaşma, pasifleşme ve özünden uzaklaşma sorunsalına dikkat çekmeye çalıştık.

Kendine yabancılaşan birey gücünü ve etkisini kaybetmekte, toplumsal çevresine etkileyen dominant bir karakter değil, çevreden etkilenen pasif biri haline dönüşmektedir. Burada sorgulanması gereken başlıca mesele şudur: Kendine yabancllaşma ve beraberinde gücünü kaybederek pasif bir varlığa dönüşme problemi bütün bireylerde aynı derecede mi gerçekleşmektedir. Bu konuda çok net bir şekilde cevabımız "hayır" olacaktır. Zira toplumsal kurumların baskısı bütün bireyler için eşit ölçüde gerçekleşmemektedir. Ya da başka bir ifadeyle toplumsal kurumların hedef kitlesi zaman zaman değişiklik gösterebilmektedir. Örneğin bir inanç sistemi müntesipleri üzesinde mutlak bir baskı yaratabilirken bu grubun dışında olan bireyler için bunun tam tersi bir tavır takınabilir. Ya da yine kültürün küçük yaştaki bir çocuktan beklentileri ile yetişkin insanlardan beklentileri aynı olmayabilir. Cinsiyet de bu konuda yaygın bir şekilde belirleyiciliği olan bir değişkendir.

Bu konuda yapılan araştırmalar ortaya koymuştur ki tarih boyunca bütün toplumlar ve bütün sistemlerde kadın ile erkeğin kurumlar karşısındaki statüsü ve bu kurumlara karşı sorumlulukları birbirinden farklı olmuştur. 
Başta inanç sistemleri olmak üzere, siyasal sistemler, kanunlar, gelenekler, ekonomik yaşam biçimleri, eğitim kurumları ve daha birçok toplumsal sistem ve kurum erkeği nispeten özgür bırakırken kadın cinsiyeti üzerinde daha şiddetli bir tahakküm uygulamıştır. Simone De Beauvoir'in ifade ettiği gibi kadının içinde bulunduğu bu durum ve durumlar bir takım önemsiz değişiklikler olsa da hep aynı kalmış, kadın kişiliğinin oluşmasında etkili olmuştur (Beauvoir, 1993, s. 7). Bu tahakkümün çeşitli sebepleri, koşulları ve açıklamaları vardır. Fakat konu alanımız dışına çıktığı için burada bunların sebepleri üzerinde durmayıp sadece şunu ifade edeceğim. Kadınlar her zaman erkeklerin yaratmış olduğu ve kendilerine ait olmayan bir yaşam biçimine sahip olmuş ve burada ikinci derecede bir yer edinebilmişlerdir. Erkeklerin kurduğu ve yönettiği dünyada kadınlar sadece kendileri uygun görülen rol ve statüler edinebilmiş, maruz kaldıkları tahakküme boyun eğmişlerdir (Beauvoir, 1993, s. 7-8). Erkek egemenliğinin olduğu kurumların ortaya koyduğu bu tahakküm eşitsizliği neticesinde ortaya çıan durum burada ifade etmeye çalıştı̆̆ımız farklılıkları doğurmaktadır. Yani kurumların yaptığı baskı neticesinde kadınlar erkeklere oranla kendinden daha çok uzaklaşmakta ve kendine daha fazla yabancılaşmaktadır. Zira tarih boyunca kadının ne giyeceği, ne yapacağı, nasıl davranacağı, kimimle evleneceği, hangi mesleğe yöneleceği, kimlerle görüşeceği, nelerden hoşlanacağ 1 ve daha birçok önemli önemsiz mesele sosyal sistemler tarafından belirlenmiş, kadına bu konularda pek söz hakkı tanınmamıştır.

Simone De Beauvoir, kadının kendinden ve geçmişinden koparak yeni bir benlik ve kimlik oluşturup özüne yabancılaşmaya başladığı süreci şu cümlelerle anlatır:

Kadın, erkeğin soyadını alır; onun dinine, sınıfına, ortamına girer; onun ailesinden biri, "yarısı" olur. Erkeğin işi nerdeyse o da oraya gider: aile, erkeğin çalıştı̆̆ yerde oturur; kadın, yavaş yavaş ya da birdenbire geçmişinden kopar, kocasinm evrenine katılır, ona verir kendini: hem kızlğını, hem de ölene dek kendisine bağh kalmaya söz verir. Yasalarm evlenmemiş kıza tanıdı̆̆ haklarm bir bölümünü yitirir. Roma Hukuku, kadını loco filioe (oğul gibi sayılan) kocaya teslim etmekteydi. XIX. Yüzyll başlarmnda, Bonald, annesi için çocuk neyse, koca için de karmmn o olduğunu söylüyordu; 1942'de kabul edilen yasaya dek, Fransız Hukuku da kadından kocasina boyun eğmesini istemekteydi; yasa ve töreler bugün de erkeğe büyük bir yetki vermektedir: bu yetke, erkeğin aileye dayanan toplum içerisindeki yerinden gelmektedir (Beauvoir, 2010, s. 15-16). 
Kocanın soyadını alan kadın geçmişini ve eski kimliğini bırakıp yeni bir kimlik edinmeye başlamaktadır. Yeni kimlik ve yaşam biçimi edinme sürecinde ise zamanla tutkuları, alışkanlıkları, günlük pratikleri, sosyal ilişkileri, ait oluğu gruba dair statü ve düşünceleri, duyguları vesair öz kimliğiyle ilgili olan neredeyse her şeyi değişme, asimile olma, unutma ve bunların toplamı anlamına gelen kendine yabancılaşma dediğimiz şeyi yaşar. Soyadı, daha önce de ifade ettiğimiz gibi bireyin ait olduğu grubu ifade etmektedir ve gruba dâhil olan bir birey artık kendini grubun normlarıyla yeniden ifade etme süreci yaşayacak, önceki benliğiyle ilgili yeni düzenlemeler yapmak durumunda kalabilecektir. Yasaların, kadını soyadı ve aile nüfus kayıtları noktasında erkeğe bağımlı hale getirmesi ve çeşitli işlemler yürütülürken kadının yok sayılması yine yabancılaşma yaşanmasına sebep olmaktadır. Zira Cevizci, kendini toplumsal ilişkilerden dışlanmış ve etkisiz biri olarak hisseden bireyde özünden uzaklaşma ve yabancılaşmanın ortaya çıktığını ifade etmektedir. Yabanclaşma kavramında vurgulanan bir başka nokta da bireyin alışık olduğu norm ve değerleri değiştirmesi durumunda ortaya çıkacak olan kaotik durumdur. Evlenmekle birlikte önce soyadını daha sonra da ait olduğu akrabalık grubunu, kimi zaman da yaşadığı yeri değiştiren kadının burada bahsi geçen değişimi yaşaması ve sonrasında da yeni dâhil olduğu grubun normlarına uyum sağlamaya çalışırken yeni bir benlik inşa etmesi başlı başına bir yabancılaşma süreci olarak değerlendirilebilir. Cevizci, bunlara ilaveten bireyin yabanclaşmasının toplumun norm ve değerlerinden uzaklaştığı ve toplumsal ilişkilerde dışlanmışlık hissine kapıldığı zaman ortaya çıktığını belirtmektedir. Bu konuda yaşanacak ikinci bir yeniden yabancilaşma süreci de boşanma durumlarında gerçekleşebilmektedir. Karı-kocanın boşanması durumunda yaşanan isim sorunu bugün dahi kadın aleyhine çeşitli olumsuz durumlar doğurabilmektedir. Zira kadın eşinden boşandıktan sonra şayet evlenirken eşinin soyadını almış ise yeniden bir isim değiştirme durumu ile karşı karşıya kalacak ve sil baştan yeni bir öz oluşturma serüveni başlayacaktır.

\section{Sonuç}

Araştırmamızda kişiliğin en önemli unsurlarından biri olan ad/soyad meselesini benlik ve kimlik inşası üzerinden değerlendirip bu açıdan kadınların yaşadığı kimlik kaybını ortaya koymaya çalıştık.Sosyoloji, psikoloji ve sosyal psikoloji alanlarında yapılan çeşitli araştırmaları inceledik ve bu konularda 
ortaya atılan çeşitli tespitlerden ve yapılan araştırma bulgularından yararlandik.

Ünlü antropolog Clifford Geertz, bireylerin kişi olarak değil toplumda üstlendikleri rol ve statü olarak önem elde ettiklerini ifade etmektedir. Bu nedenle taktıkları maskeler, içinde bulundukları sahne ve oynadıkları oyun onların kalıcı bir şekilde benliklerini oluşturmaktadır. (Kağıtçıbaşı, 2019, s. 113). Yine Geertz, Bali'de kişilerin isimlerinin pek anlamsız olduğunu, onların özellikle kimin çocuğu olduklarıyla, yani toplumdaki konumlarıyla ifade edildiklerini belirtmektedir (Kağıţ̧ıaşı, 2019, s. 113). Aynı gelenek yakın zamanlara kadar bizlerin de pek yabancı olmadığı, çalışmamız başında bahsettiğimiz ve soyadı yasaları öncesinde yaygın bir şekilde uygulanan bir yöntemdir. Daha önce de belirttiğimiz gibi ad, bireyi ifade etmekteyken, soyadı o bireyin kimlerden olduğunu ve nasıl bir statüye sahip olduğunu göstermektedir. Soyadı, kategoriler halinde sürdürdügümüz günlük yaşamda hangi kategoride olduğumuzu göstermektedir. Gerçekten de gündelik yaşamda çoğu zaman bireyin kim olduğundan ziyade kimlerden olduğu daha önemli olmaktadır

Ad ve soyad kişiyi bir taraftan birey olarak etiketlemekteyken diğer taraftan da sosyal ilişkilerini ortaya koyup kolektif statüsünü göstermektedir. İnsanlar sosyal yaşantılarında nasıl ki diğer insanlarla ilişki kurmak ve mevcut ilişkilerinde pozisyon almak zorundaysa yine aynı nedenle bir soyadı kullanması ve onu koruması gerekmektedir. Ad ve soyad öncelikle insanoğlunun birey olmasını sağlamakta, ardından ona resmiyet kazandırmaktadır. Aslında bu konu modern toplumda insanoğlunun ontolojik bir sorunu olmuştur. Ad, bireyin var olduğunun bir kanit, soyad ise onun kim olduğunun resmi bir belgesidir. Bu belge ona kanunlar tarafindan verilmekte ve en temel kişilik hakkı olarak tanınmaktadır. Fakat görülmektedir ki kanunlar bir taraftan ad ve soyadı en temel hak olarak görmekteyken diğer taraftan bu hakkı görmezden gelip kadının elinden alınmasına göz yummaktadır. Şüphesiz ki toplum yaşantısında, geleneklerin, alışkanlıkların ve insan davranışlarının üzerinde etkili olan, yine onların ortaya çıkmasında, değişmesinde veya ortadan kalkmasinda belirleyici bir faktör olan kanunlar veya çeşitli yasal düzenlemeler, soyadı uygulamasında kadın erkek arasında asimetrik bir ilişkisinin oluşmasına zemin hazırlamıştır. Bu konuda yakın tarihlerde kadın lehine çeşitli düzenlemeler yapılmış ve devletler yine kadın lehine çeşitli politikalar geliştirmiştir. Bu olumlu gelişmeler kadının deza- 
vantajının giderilmesi anlamında büyük katkı sağlamış olsa da birçok insan yüzyıllar boyunca süregelen geleneklerini terk etmek istememiştir. Kadınların gerek evlendikleri zaman kocalarının soyadına geçmesi gerekse aile kayitlarının değişmesi onlar üzerinde bariz bir kimlik ve benlik değiştirme etkisi yaratmıştır. Bununla kalmamış, kadınlar boşanma durumlarında da aynı kimlik kaybı sorununu yaşamış ve modern kent toplumu içerisinde zaman zaman statüsünü, zaman zaman da sadece benlik ve kimliğini kaybedip yeniden kazanmak ve inşa etmekle karşı karşıya kalmıştır.

Soyadı uygulaması aslında günümüz toplumlarının kalabalıklaşmasının getirdiği bir çok yaşam stili uygulamalarından biridir. Bu gün bizler kalabalık toplumlar içerisinde her geçen gün daha da yalnızlaşan, yalnızlaşırken de bir o kadar etrafındakilere bağımlı hale gelen varlıklarız. Yaşamımızı kolaylaştırmak, yardımlaşmak ve daha bunun gibi birçok günlük ihtiyaçtan dolayı küçük gruplara ayrılıp diğerleriyle olan ilişkilerimizi yapılandırma ve sinırlandırma gereği duymaktayız. Bir taraftan toplumla birlikte kalabalıklaşırken diğer taraftan da bireysel anlamda yalnızlaşma sorunu bizi bu kategorileşme sürecine adeta mecbur bırakmaktadır. İşte bu nedenle bizler soyadı ve aile kaydı uygulamasını modernleşme ve kentleşme süreçleriyle birlikte değerlendirmeliyiz.

Kadın, bütün toplumlarda uzun yıllar boyunca evin içinde tutulmuş, ev dışında neredeyse bütün yaşam alanlarından uzak kalmıştır. Bununla ilgili birkaç örnek verilebilir. Uzun yıllar boyunca kadınların kocalarını boşaması, sokaklarda veya kamuya açık çeşitli mekânlarda dolaşmaları, ticaret yapmaları, çeşitli toplu taşıma araçlarını kullanmaları, eğitim almaları, bir meslek dalına yönelmeleri, resmi işlemler yapmaları, siyasetle ilgilenmeleri, oy kullanmaları ve daha bunun gibi birçok kişisel hakları yasalarla engellenmiştir. Fransa'da kanunlar erkeklere mülkiyeti kullanma konusunda tam yetki verip kadını kendine ait olan malları bile kullanma hakkından mahrum bırakmış, kadın uzun yıllar boyunca bu konuda kocasının himayesinde olmuştur (Arnaud-Duc, 2005, s. 105). Yine İngiltere'de kadınlar, yakın zamanlara kadar mülklerinin ve kazançlarının üzerinde tasarruf hakkına sahip olamamış, kadının yasal kişiliği ancak 1870'lerde kabul edilmiştir. Ünlü İngiliz hukukçu Blackstone "koca ile karı birdir ve bu bir kocadır" sözüyle aslında dönemin kadın politikasını yansıtmıştır. Yirminci yüzyılın ilk yarısında İspanya'da reşitlik yaşı yirmi beşe yükseltilerek kadınlar evlenene kadar babalarının himayesine teslim edilmiştir (Genevois, 2005, s. 180). Buradaki 
örneklerin tamamı kadının resmi bir kişilik olarak tanınmadığına, bu nedenle de yasal bir kimliğe erkekler kadar ihtiyaç duymadığına örnektir. Fakat kent yaşamının ortaya çıkması, modern toplum tipinin yaygınlaşması gibi gelişmeler kadınların bahsettiğimiz bu yaşam alanlarında varlıklarını sürdürmelerine imkân sağlamış ve artık onun da erkekler gibi resmi bir kimliğinin olması gerekli hale gelmiştir. Kısaca modern yaşam biçimleri sokakta, iş yerinde, siyasette, ticarette ve daha birçok yerde kadının varlık problemine nispeten bir çözüm ortaya koymuştur.

Yine de kadının, soyadı uygulamalarında uzun yıllar boyunca hayatındaki iki egemen erkekten birine baba ya da kocaya bağımlı bir figür olarak görülmesi toplumların yaşantılarında çeşitli gelenekler ve temayüllerin oluşmasına zemin hazırlamıştır. Bu gün gelinen noktada kadının, gelenekler ve temayüllerle birlikte mağrurlaşan erkek karşısında mağdurlaştığı görülmektedir. Bu mağduriyet sadece statü anlamında değil bireysel kimlik ve benlik algisı anlamında da değerlendirilmelidir.

Son olarak toplumda soyun erkek üzerinden yürüdüğüne dair var olan geleneksel düşünceyi de bu tartışma konusu içine sokmanın yanlış olmayacağı kanaatindeyim. Bu düşünce yapısının bilimsel bir alt yapısı bulunmamaktadır. Zira insan yavrusunun oluşmasında anne ve babadan eşit sayıda kromozom gelmekte ve bebeğin genetik özellikleri her iki ebeveynden de alınmaktadır. Hal böyleyken soyun babadan yürüdüğü düşüncesi bütün geleneklerde hâkim düşünce olmuştur ve bu gün de bu geleneksel düşünce tamamen terkedilmiş değildir. Bunun için kendimize şu soruyu yöneltelim. Şayet eskiden beri var olan soyadı ve aile kaydı uygulaması kadın lehine olsaydı, yani evlenirken erkek kadının soyadını alsaydı ve yine kadının aile kütüğüne nakledilseydi yine de soyun babadan yürüdügü düşüncesi hâkim olur muydu? Öyle zannediyorum ki kadının, bu konuda kocanın gölgesinde kalması ve erkeğin egemen pozisyonda olup kadın varlı̆̆ının neredeyse yok sayılmasında tartıştı̆̆ımız bu yasal uygulamaların önemli bir etkisi olmuştur.

Bu konuda çok uzun yıllar boyunca yaygın gelenekler ortaya çıkmıs, kadınlar çok defa ve yaygin bir biçimde mağduriyetler yaşamıştır. Hatta bu mağduriyetler zaman zaman insanların inanç sistemlerini bile etkilemiştir. Bu nedenle soyadı ve aile kaydı konusunda yapılması gereken çeşitli eşitlikçi düzenlemeler bir taraftan kadını da soyun murisi haline getirecek, diğer taraftan da yaşanan kimlik kaybı sorununa çözüm anlamında katkı sağlayacaktır. 


\title{
EXTENDED ABSTRACT
}

\section{A Explication Abaout The Problem Of The Married Woman's Surname And Loss Of Identity}

\author{
İbrahim Aksakal \\ Erzincan Binali Yildırım University
}

Women's studies is one of the important problem areas that researchers have focused on for many years. In this research area, gender inequality and the issues that set the ground for this inequality are among the dominant research problems. Again, one of the frequently discussed issues in this regard is the woman's surname problem. The surname problem of women has been the subject of many studies. In this study, unlike the others, the relationship between the women's surname problem and identity construction and alienation was tried to be established, and in this process, it was tried to focus on the women's identity crisis problem.

This study suggests that "surname changes in women who get married and maybe divorce later cause a loss of identity or self-perception problem in them?" and tried to find the answer to this problem. For this purpose, first the sub-headings of "the surname problem in women", "the construction of self and identity in the individual" and "the alienation of the individual" were discussed, and then our research problem was evaluated in line with the information obtained and the study was terminated with various suggestions.

Many studies have revealed that the surname is an important factor in the individual's association with the group he / she belongs to and establishing a relationship of belonging. Individuals determine which family and group they belong to with the help of their surname. With the inclusion of the individual in the group, he will now experience a process of reexpressing himself with the group's norms, and may have to make new arrangements about his previous self. Because, a relationship dependent on the social environment in which the individual, who is a social being, is in, tries to continue his life with this group. Human beings are one of the species that most need an adult in the world. From the moment he opened his eyes to life until the end of his life, he needs the help of other people on va- 
rious issues. People have many needs that need to be met, from nutrition to shelter, from being loved to the need for belonging. Therefore, we can say that it is in the nature of man to be included in a group and to express himself with that group. This group is a family and the family has always been a male-dominated structure. The surname is the general name of the family and is a male-dominated subject. When a woman uses a surname, it falls under male domination and creates a social identity with this name her father gave her. The part so far has been frequently stated in other studies. But the point we are trying to draw attention to here is this: Although the surname of the woman changes after her marriage, she also changes the family group she is included in. This new identity brings about many changes in his life. Perhaps new norms and values will wait for a woman who has abandoned her old identity and become a member of a new kin group, she will abandon many of her old habits and may have to establish a new lifestyle for herself. Because successful identity requires adapting to the environment it is in. If the woman wants to be successful in her social relations, she needs to be at peace with the norms and values of the new group she is a member of. In addition to this, the tahak-cum that the group exerts on the individual is another detail that necessitates this harmony. Also, in traditional societies, this domination is applied more to women than men. Because women have been the representative of various values in most societies. For example, the woman was seen as the honor of the family and her behavior against social values was equated with the assimilation of the values of the whole group. It is for this reason that the group pressure to which women are subjected has almost always been more intense than men.

Another point we have dealt with on this issue is this: For many years, there is a traditional idea that the lineage is based on men in societies and this mentality has not disappeared even in today's societies. This mentality is not a scientific foundation, but a result of male-dominated lifestyle. Because, in the formation of a human baby, an equal number of chromosomes come from the mother and father, and the genetic characteristics of the baby are taken from both parents. And yet, the idea that lineage is descended from father has been the dominant thought in all traditions. For this, let's ask ourselves the following question. If the long-standing surname and family registration practice were in favor of the woman, that is, if the man took the woman's surname when he got married and was transferred to the 
family register of the woman, would the idea that the lineage walked from the father still prevail? I think that these legal practices, which we have discussed, had an important effect on the fact that the woman remained in the shadow of the husband and the man was in the dominant position and the existence of women was almost ignored. For many years, widespread traditions have emerged on this issue, and women have suffered many times and widespread. In fact, these victimizations have even affected people's belief systems from time to time. For this reason, various egalitarian regulations regarding surname and family registration will, on the one hand, make women the murderers of the family, on the other hand, will contribute to the solution to the problem of identity loss.

In summary, in this study, the problematic of the surname of women was discussed in terms of self and identity construction. It has been pointed out that this problem is a loss of identity stemming from male domination. It has been criticized that this loss of identity is not a women's creation feature, but an artificial identity problem. In fact, criticism was made that the legal regulations contributed to the victimization of women, and the regulations on the surname and population registration procedures made recommendations that the issue should be evaluated in this respect and the research was ended.

\section{Kaynakça / References}

Abik, Y. (2005). Kanının soyadı ve buna bağlı olarak çocuğun soyadı. Ankara: Seçkin Yayınevi.

Aksakal, İ. (2019). Devlet söyleminde toplumsal cinsiyet.Doktora Tezi, Atatürk Üniversitesi Sosyal Bilimler Enstitüsü. Erzurum

Aranson, E., Wilson, T. D., ve Akert, R. M. (2012). Sosyal psikoloji. (Çev.: O. Gündüz), İstanbul: Kaknüs Yayınevi.

Arnaud-Duc, N. (2005). Hukukun çelişkileri. G. Duby, M. Perrot, ve G. F. Fethi Kadınların Tarihi IV, (Çev.: A. Fethi), içinde (s. 80-110). İstanbul: Türkiye İş Bankası Kültür Yayınları.

Atasoy, H. (2015). Evli kadının soyadı sorunu "anayasal" mı? "bireysel" mi?" Uyuşmazlık Mahkemesi Dergisi, 5, 131-170.

Beauvoir, S. D. (1993). Kadın İkinci Cins III: bağımsızlı̆a doğru. (Çev.: B. Onaran), İstanbul: Payel Yayınevi. 
Beauvoir, S. D. (2010). Kadın ikinci cins evlilik çă̆̆. (Çev.: B. Onaran), İstanbul: Payel Yayınevi.

Bhasin, K. (2003). Toplumsal cinsiyet. (Çev.: K. Ay), İstanbul: Kadav Yayınları.

Bilgin, N. (2007). Kimlik inşası. İzmir: Aşina Kitaplar Yayınevi.

Cauly, O. (206). Kierkegaard. (Çev.: I. Ergüden ), Ankara : Dost Yayınevi.

Cevizci, A. (2005). Felsefe sözlüğü. İstanbul: Paradigma Yayınevi.

Ellemers, N., ve Haslam, A. (2012). Social identity theory. P. A. Lenge, A. W. Kruglanski, ve E. T. Higgins, Theories of Social Physhology içinde (s. 379398). Los Angeles, London, New Delhi, Singapore, Washington DC: Sage Publications.

Erdoğan, İ. (1998). Şahsiyeti incitici soyadı meselesi. Selçuk Üniversitesi Hukuk Fakültesi Dergisi, 6 (1-2), 705-712.

Freud, S. (1994). Psikanaliz üzerine. (Çev.: K. Şipal), İstanbul: Say Yayınları.

Freud, S. (2011). Haz ilkesinin ötesinde ben ve id. (Çev.: A. Babaoğlu), İstanbul: Metis Yayınları.

Genevois, D. B. (2005). Cumhuriyet'ten Franco'ya İspanya'nın kadınları. G. Duby, M. Perrot, ve F. Thebaud, Kadınlarn Tarihi V, Yirminci Yüzyılda Kültürel Bir Kimliğe Doğru (Çev.: A. Fethi) içinde (s. 168-182). İstanbul: Türkiye İş Bankası Kültür Yayınları.

Goffman, E. (2016). Günlük yaşamda benliğin sunumu. (Çev.: B. Cezar), İstanbul: Metis Yayınevi.

Goffman, E. (2018). Damga örselenmiş kimliğin idare edilişi üzerine notlar. (Çev.: Ş. Geniş-L. Ünsaldı-S.N. Ağırnaslı), Ankara: Heredik Yayınevi.

Gürlek, M., ve Tuna, M. (2018). Sosyal kimlik teorisi açısından örgütsel özdeşleşmenin teorik temelleri. Yönetim, Ekonomi ve Pazarlama Araştırmaları Dergisi, 2 (3), 39-48.

Hogg, M. A., ve Abrams, D. (1998). Social identifications: A social psychology of intergroup relations and group processus. London: Routledge.

Hogg, M. A., ve Vaughan, G. M. (2014). Sosyal psikoloji. (Çev.: İ. Yıldız), Ankara: Ütopya Yayincilik.

İlgöz, S. (2009). Esitlik bağlamında kadının soyadı sorunu. UluslararasıDisiplinlerarası Kadın Çalışmaları Kongresi, Sakarya: Sakarya Üniversitesi Rektörlüğü. 105-118.

İzmir, M. (2013). Öznenin diyalektiği Hegel, Sartre ve Lacan. Ankara: İmge Yayınevi. Kağıtçıbaşı, Ç. (2019). Benlik, aile ve insan gelişimi . İstanbul: Küy Yayınevi.

Küçükkalp, K. (2010). Husserl Fikir mimarları dizisi. Ankara: Say Yayınları. Lacan, J. (1994). Fallusun anlamı. (Çev.: S. M. Tura), İstanbul: Afa Yayıncılık. 
Lamber, J. C. (1973). A married woman's surname: Is custom law? Washington University Law Review, 778-819.

Marshall, G. (1999). Sosyoloji sözlüğ̈̈̈. (Çev.: O. Akınhay, D. Kömürcü), Ankara: Bilim ve Sanat Yayınevi.

Moroğlu, N. (2012). Kadının soyadı. Türkiye Barolar Birliği Degisi, 99,1-22.

Myers, D. G. (2015). Sosyal Psikoloji. (Çev. Ed.: Serap Akfırat), Ankara: Nobel Yayınevi.

Ouspensky, P. D. (2010). İnsanın gerçeği "kendini bilmek". (Çev.: A Belbez, E. Konyalığlu), İstanbul: Ruh ve Madde Yayınları.

Özkan, K. (2014). Kadınların kolektif eylem yöneliminin yordayıcıları: Kültürel benlik kurguları, kadın kimliği ile özdeşleşme, kadınların sosyal baskınlık yönelimi ve sistemi meşrulaştırma ĕ̆ilimi. Bursa: Uludağ Üniversitesi.

Pilcher, J. (2017). Names and "doing gender": how forenames and surnames contribute to gender identies, difference and inequalities. Sex Roles, 77, 812-822.

Robnett, R. D., Underwood, C. R., Nelson, P. A., ve Anderson, K. J. (2016 ). She might be afraid of commitment: Perceptions of women who retain their surname after marriage. Sex Roles, 75, 500-513.

Taylor, S. E., Peplau, L. A., ve Sönmez, D. O. (2012). Sosyal psikoloji. (Çev.: A. Dönmez), Ankara: İmge Yayınevi.

Uluğ, Ö. M. (2015). Soyadım kimliğimdir, evlenince kaybolmamalıdır: Hegemonik erkeklik ile medeni kanun'un 187. maddesi arasındaki ilişkiye eleştirel bir bakış., Fe Dergi: Feminist Eleştiri, 7 (2), 48-58.

\section{Kaynakça Bilgisi / Citation Information}

Aksakal, İ. (2020). Evli kadında soyadı sorunu ve kimlik kaybı üzerine bir değerlendirme. OPUS-Uluslararası Toplum Araştırmaları Dergisi, 16(30), 2883-2910. DOI: 10.26466/opus.762417 